\title{
Reactivity of Neutrophil-Like HL-60 Cells lowards Persistent Forms of Escherichia coli
}

DOI: 10.17691/stm2019.11.4.09

Received September 3, 2019

N.A. Mayansky, MD, DSc, Professor of the Russian Academy of Sciences,

Head of the Laboratory Diagnostic Center, Russian Children's Clinical Hospital';

Yu.A. Bocharova, MD, PhD, Junior Researcher2;

E.A. Brzhozovskaya, Junior Researcher";

A.V. Lazareva, MD, DSc, Head of the Laboratory of Microbiology2;

1.V. Chebotar, MD, DSc, Professor, Department of General Pathology ${ }^{1}$

1 Pirogov Russian National Research Medical University, 1 Ostrovitianova St., Moscow, 117997, Russia;

${ }^{2}$ National Medical Research Center for Children's Health, 2/1 Lomonosovsky Avenue, Moscow, 119991, Russia

The aim was to study the reactivity of neutrophil-like $\mathrm{HL}-60$ cells towards native $E$. coli and $E$. coli persisters by measuring the intensity of their respiratory burst.

Materials and Methods. Persistent forms (persisters) of $E$. coli were obtained by sequential incubation of bacteria in solutions of 3-chlorophenylhydrazone carbonyl cyanide (CCCP) and ciprofloxacin. Differentiated cells of the HL-60 line (ATCC CCL-240) were used as neutrophil-like cells. The reactive respiratory burst of neutrophil-like cells in response to native $E$. coli or $E$. coli persisters was evaluated by measuring fluorescence of the oxidized form of Amplex Red using an Infinite M200 microplate reader.

Results. The number of viable $E$. coli before and after incubation with the CCCP and ciprofloxacin was approximately the same, thus confirming the presence of persistent forms of $E$. coli. Native $E$. coli cells caused a statistically significant increase in respiratory burst of neutrophil-like cells reaching $14 \pm 4 \%$ of the positive control values (in the negative control, the values were $6 \pm 3 \%$ ). The respiratory burst intensity of neutrophil-like cells mixed with $E$. coli persisters was significantly higher than that observed with native E. coli, and accounted for $42 \pm 7 \%$ of the positive control.

Conclusion. Persists of $E$. coli can stimulate the respiratory metabolism of phagocytic neutrophil-like cells of the HL-60 line. The ability of these persisters to induce a respiratory burst of neutrophils is significantly greater than that of native $E$. coli bacteria.

Key words: bacteria; E. coli persisters; antibiotic resistance; phagocytosis; flow cytometry; respiratory burst.

\section{Introduction}

One of the most pressing problems of medical science is the progressing resistance of pathogenic bacteria to antimicrobials. Several mechanisms are known to allow bacteria to survive in the presence of antibiotics. Until recently, five types of drug-resistance were recognized: target modification, antibiotic inactivation, active removal of the antibiotic from the microbial cell (efflux), impaired permeability of the microbial wall, and the formation of metabolic "shunt" [1]. Now, this list is supplemented with two additional resistance mechanisms, namely, biofilm resistance [2] and the formation of persistent bacteria - persisters [3]. Persisters are metabolically inactive and they are not sensitive to antibiotics [4].

Currently, a significant number of researchers are studying persistent bacterial cells: in 2018, according to PubMed, more than 150 papers on this subject were published. Physiology of persistent bacteria has been studied in detail including the ways of their formation $[3,5]$ and the mechanisms of their reverse transformation into normally functioning bacteria [6]. Methods for collecting and enriching the fractions of persistent bacterial cells have been developed - it is now possible to get a bacterial population containing $80-90 \%$ of persisters [7-9]. Details of the "frozen" metabolism of these forms have been elucidated, and the molecular basis for the resistance to antibiotics has been deciphered $[10,11]$. The surface structures of persisters were studied [12] with the help of morphological and functional methods developed specifically for these bacterial forms [13]. However, questions regarding the virulence of persisters and their interaction with human tissues remain open. Particularly important is the relation between persisters and the human immune system, specifically the reactions between persisters and neutrophils, which are highly significant immunocompetent cells. By now, only the phagocyte-induced formation of persisters has been investigated [14]. The reverse side of this phenomenon, i.e., how phagocytes react to persistent bacteria, remains unknown. 
The aim of this study was to compare the reactivity of neutrophil-like HL-60 cells towards persistent and native forms of the opportunistic pathogen $E$. coli, by measuring the intensity of the respiratory burst.

\section{Materials and Methods}

Production of persistent bacteria. Persistent cells were obtained according to the standard method of bacteria cultivation. In our study, reference E. coli ATCC 25922 strains were used in a medium supplemented with $200 \mu \mathrm{g} / \mathrm{ml}$ 3-chlorophenylhydrazone carbonyl cyanide (carbonyl cyanide m-chlorophenyl hydrazine, CCCP) [15]. A $24 \mathrm{~h}$ bacterial culture was added into the Luria-Bertani broth (LB broth; Becton Dickinson, USA) until a turbidity of 0.5 units (by the MacFarland scale) was reached; then $0.5 \mathrm{ml}$ of the resulting suspension was transferred into $5 \mathrm{ml}$ of LB broth and incubated for $18 \mathrm{~h}$ at $37^{\circ} \mathrm{C}$. Three samples of $0.98 \mathrm{ml}$ were taken from the 18-hour culture.

The samples were processed in two stages. At the first stage, $0.02 \mathrm{ml}$ of CCCP (Sigma-Aldrich, USA) dissolved in dimethyl sulfoxide (DMSO; Molecular Probes, USA) at a concentration of $10 \mathrm{mg} / \mathrm{ml}$ was added in sample 1; in parallel, samples 2 and 3 were added with $0.02 \mathrm{ml}$ of DMSO. The samples were incubated at $37^{\circ} \mathrm{C}$ for $3 \mathrm{~h}$ in a shaker, then washed twice in saline and resuspended in $0.2 \mathrm{ml}$ of LB broth.

At the second stage, $0.2 \mathrm{ml}$ of LB broth with ciprofloxacin (Sintez, Russia) was added to samples 1 and 2 at a concentration of $10 \mu \mathrm{g} / \mathrm{ml}$; sample 3 was added with $0.2 \mathrm{ml}$ of LB broth with no antibiotic. The incubation was performed under the conditions described for the first stage. The samples were washed twice and resuspended in $1 \mathrm{ml}$ HEPES buffer (SigmaAldrich). To confirm the presence of persistent bacteria and the absence of native bacteria in sample 1 , control seeding from the sample was made before and after incubation with ciprofloxacin. To do this, $0.02 \mathrm{ml}$ of $100-$ fold dilutions from the sample was spread over plates with Mueller-Hinton agar (Bio-Rad Laboratories, USA). The plates were incubated for $24 \mathrm{~h}$ at $37^{\circ} \mathrm{C}$; then colony forming units (CFU) were counted. The criterion for the presence of persisters was approximately the same number of CFU grown before and after incubation with ciprofloxacin [15]. After incubation, the concentration of bacterial cells was standardized by using a NovoCyte flow cytometer (ACEA Biosciences, USA). The data analysis was performed using the NovoExpress software. For each sample, a minimum of $1 \cdot 10^{6} / \mathrm{ml}$ bacterial cells was analyzed. Quantification of bacteria was carried out without using fluorescent dyes; instead we measured direct and side light scattering by each bacterial cell.

Preparation of phagocytic cells: cultivation and differentiation of $\mathrm{HL}-60$ cells. A promyelocytic line of HL-60 cells (ATCC CCL-240) at the stage of myeloblast development was used as a source of phagocytic neutrophil-like cells. To create a culture medium, fetal bovine serum (HI FBS; Gibco, USA) was added to the minimum nutrient medium (IMDM) to a final concentration of 20\%, L-glutamine (Glutamax; Gibco) to a final concentration of $1 \%$, and penicillin-streptomycin (Pen Strep; Gibco) to a final concentration of $1 \%$. The cell line was grown to a level of $(5-8) \cdot 10^{5} \mathrm{cells} / \mathrm{ml}$ in the complete medium and passaged every 3-4 days by centrifugation at $1500 \mathrm{rpm}$ for $5 \mathrm{~min}$. To start the differentiation process, the cell culture concentration was adjusted to a density of $3 \cdot 10^{5} \mathrm{cell} / \mathrm{s} / \mathrm{ml}$ and incubated overnight to obtain an exponentially growing cell culture. These cells were brought to a density of $3 \cdot 10^{5} \mathrm{cell} / \mathrm{s} / \mathrm{ml}$ in the complete nutrient medium supplemented with DMSO to a final concentration of $1.25 \%$ in order to induce differentiation and maturation of neutrophillike cells. After 5 days of differentiation, HL-60 cells were washed by centrifugation at $1500 \mathrm{rpm}$ for $5 \mathrm{~min}$, the supernatant was removed and the cell suspension washed by centrifugation in HEPES buffer enriched with $\mathrm{Ca}^{2+}$ and human serum albumin. After the washing, cells were diluted in the same buffer; their viability was assessed using trypan blue. After the counting, the cells were adjusted to a concentration of $1 \cdot 10^{6} / \mathrm{ml}$ in the complete HEPES buffer to study the respiratory burst reaction.

Respiratory burst assay. To assess the respiratory burst of neutrophil-like HL-60 cells in reaction with native and persistent $E$. coli (bacteria/phagocyte ratio; 40/1), we used the well-known method based on fluorescence of oxidized Amplex Red dye (Molecular Probes, USA). Phorbol 12-myristate 13-acetate was used as a positive reaction control, and HEPES buffer was used as a negative control. The results were expressed as the percentage of the fluorescent signal (slope of the curve for $30 \mathrm{~min}$ of reaction) generated by neutrophil-like HL-60 cells in the presence of phorbol 12-myristate 13-acetate. The fluorescence was measured using an Infinite M200 microplate reader (Tecan Group Ltd., Switzerland). Kinetics of the resulting fluorescence (indicator of the respiratory burst) was monitored for $40 \mathrm{~min}$ by measuring the fluorescence signal (excitation $545 \mathrm{~nm}$ and emission $590 \mathrm{~nm}$ ) every minute. All experiments were performed in 4-6 replicates; all measurements made in triplicates were included in the final results.

All results were statistically processed using the standard software embedded into the Infinite M200 reader.

\section{Results and Discussion}

The number of viable bacteria before and after incubation with ciprofloxacin was similar and amounted to $3.3 \cdot 10^{5}$ and $3.2 \cdot 10^{5} \mathrm{CFU} / \mathrm{ml}$, respectively $(p>0.05)$. According to the criteria of Grassi et al. [15], this result indicated that sample 1 added with ciprofloxacin contained mostly persistent $E$. coli bacteria.

A typical respiratory burst in neutrophil-like HL-60 


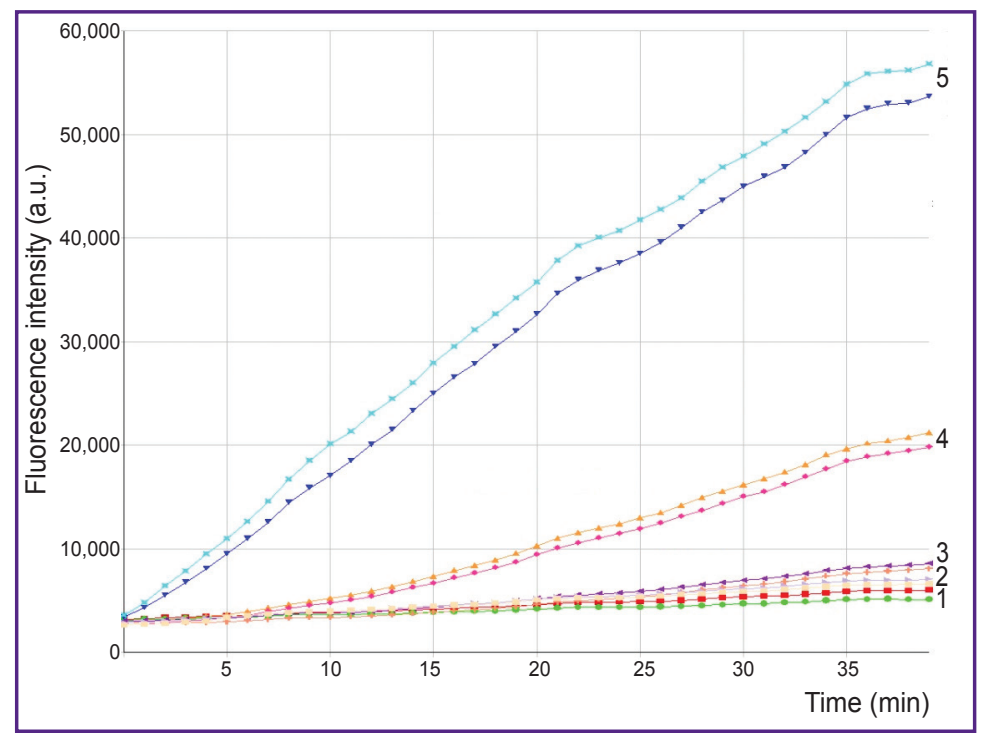

A typical respiratory burst reaction (two repetitions) of neutrophil-like HL-60 cells towards native $E$. coli bacteria (3) and E. coli persisters (4). Positive control (5) - stimulation by phorbol 12-myristate 13-acetate; negative control (2) - HEPES buffer. Unstimulated neutrophil-like cells HL-60 (1)

Kinetics of the respiratory burst in neutrophil-like HL-60 cells when interacting with native bacteria and persisters (the mean slope for $30 \mathrm{~min}$ of reaction)

\begin{tabular}{|lc}
\hline \multicolumn{1}{|c}{ Conditions of cell stimulation } & \multicolumn{1}{|c}{$\begin{array}{c}\text { Average slope } \\
\text { of the curve } \\
\text { (\% of the positive } \\
\text { control value) }\end{array}$} \\
\hline Negative control (HL-60 cells + HEPES buffer) & $6 \pm 3^{*}$ \\
\hline Positive control (HL-60 cells + phorbol & 100 \\
\hline 12-myristate 13-acetate) & $14 \pm 4^{*+}$ \\
\hline HL-60 cells + E. coli, native cells & $42 \pm 7^{+}$ \\
\hline HL-60 cells + E. coli persisters
\end{tabular}

* Statistically significant differences between the negative control values and the respiratory burst in contact with native E. coli, $\mathrm{p}=0.048$; $^{+}$statistically significant differences between the respiratory burst values in the presence of native $E$. coli and $E$. coli persisters, $\mathrm{p}=0.017$.

cells in response to persistent and native $E$. coli is shown in the Figure. The respective statistics is presented in the Table. Native E. coli caused a significant acceleration of Amplex Red fluorophore oxidation by neutrophil-like cells: the slope of the curve was $14 \%$ of the positive control value $(6 \pm 3 \%$, in the negative control). Amplex Red oxidation in the " $E$. coli persisters-neutrophil-like cells" system was significantly higher than that observed with native E. coli, and reached $42 \pm 7 \%$ of the positive control.

The results show that both the native bacteria $E$. coli and E. coli persisters have the ability to activate the respiratory metabolism of phagocytes. However, neutrophil-like cells responded to $E$. coli persisters more actively than it did with native bacteria. This may be due to a reduced metabolic profile of persisters [8].
Inhibition of metabolism inevitably leads to a slowdown in all energy-dependent reactions in a bacterial cell, including the escape from immune effectors. Native bacteria with normal energy metabolism retain and exhibit the anti-phagocytic properties, thus reducing phagocytosis and respiratory burst of neutrophils. This mechanism has been proposed for all bacteria with pathogenic potential [16]. E. coli cells are no exception: their virulence is maintained by energy-dependent processes; when the cell energetics is blocked, the anti-phagocytic defense is also blocked [17]. In terms of antibacterial immunity, our observation sounds encouraging: persistent bacteria can be eliminated by phagocytosis.

\section{Conclusion}

The obtained results allow us to draw several important conclusions. Firstly, persistent bacteria E. coli can stimulate the respiratory metabolism of phagocytic neutrophil-like $\mathrm{HL}-60$ cells. Secondly, the ability of $E$. coli persisters to stimulate a respiratory burst of neutrophils is much more pronounced than that of native $E$. coli bacteria. This suggests that the most important immunity effectors, neutrophils, are capable of recognizing and attacking $E$. coli persisters.

Research funding. This work was financially supported by the Russian Foundation for Basic Research (project No.18-015-00301 "Neutrophil reactivity in interaction with gram-negative persistent bacteria").

Conflict of interest. The authors declare no conflicts of interest.

\section{References}

1. Prakticheskoe rukovodstvo po antiinfektsionnoy khimioterapii [A practical guide to anti-infectious chemotherapy]. 
Pod red. Strachunskogo L.S., Belousova Yu.B., Kozlova S.N. [Strachunskiy L.S., Belousov Yu.B., Kozlov S.N. (editors)]. Smolensk: NIIAKh SGMA; 2002; 586 p.

2. Chebotar I.V., Mayansky A.N., Konchakova E.D., Lazareva A.V., Chistyakova V.P. Antimicrobial resistance of bacteria in biofilms. Klinicheskaya mikrobiologiya $i$ antimikrobnaya khimioterapiya 2012; 14(1): 51-58.

3. Lewis K. Persister cells. Annu Rev Microbiol 2010; 64(1): 357-372, https://doi.org/10.1146/annurev. micro.112408.134306.

4. Evdokimova N.V., Tchernenkaya T.V. Persister microbial cells: a novel view on the old problem. Klinicheskaya mikrobiologiya i antimikrobnaya khimioterapiya 2013; 15(3): 192-197.

5. Wood T.K., Knabel S.J., Kwan B.W. Bacterial persister cell formation and dormancy. Appl Environ Microbiol 2013; 79(23): 7116-7121, https://doi.org/10.1128/aem.02636-13.

6. Jõers A., Kaldalu N., Tenson T. The frequency of persisters in Escherichia coli reflects the kinetics of awakening from dormancy. J Bacteriol 2010; 192(13): 3379-3384, https:// doi.org/10.1128/jb.00056-10.

7. Kaldalu N., Jõers A., Ingelman H., Tenson T. A general method for measuring persister levels in Escherichia coli cultures. Methods Mol Biol 2016; 1333: 29-42, https://doi. org/10.1007/978-1-4939-2854-5_3.

8. Fisher R.A., Gollan B., Helaine S. Persistent bacterial infections and persister cells. Nat Rev Microbiol 2017; 15(8): 453-464, https://doi.org/10.1038/nrmicro.2017.42.

9. Helaine S., Kugelberg E. Bacterial persisters: formation, eradication, and experimental systems. Trends Microbiol 2014; 22(7): 417-424, https://doi.org/10.1016/j. tim.2014.03.008.

10. Prax M., Bertram R. Metabolic aspects of bacterial persisters. Front Cell Infect Microbiol 2014; 4: 148, https://doi. org/10.3389/fcimb.2014.00148.

11. Amato S.M., Fazen C.H., Henry T.C., Mok W.W., Orman M.A., Sandvik E.L., Volzing K.G., Brynildsen M.P. The role of metabolism in bacterial persistence. Front Microbiol 2014; 5: 70, https://doi.org/10.3389/fmicb.2014.00070.

12. Molina-Quiroz R.C., Lazinski D.W., Camilli A., Levy S.B. Transposon-sequencing analysis unveils novel genes involved in the generation of persister cells in uropathogenic Escherichia coli. Antimicrob Agents Chemother 2016; 60(11): 6907-6910, https://doi.org/10.1128/aac.01617-16.

13. Orman M.A., Brynildsen M.P. Establishment of a method to rapidly assay bacterial persister metabolism. Antimicrob Agents Chemother 2013; 57(9): 4398-4409, https:// doi.org/10.1128/aac.00372-13.

14. Fisher R.A., Cheverton A.M., Helaine S. Analysis of macrophage-induced salmonella persisters. Methods Mol Biol 2016; 1333: 177-178, https://doi.org/10.1007/978-1-49392854-5_15.

15. Grassi L., Di Luca M., Maisetta G., Rinaldi A.C., Esin S., Trampuz A., Batoni G. Generation of persister cells of Pseudomonas aeruginosa and Staphylococcus aureus by chemical treatment and evaluation of their susceptibility to membrane-targeting agents. Front Microbiol 2017; 8: 1917, https://doi.org/10.3389/fmicb.2017.01917.

16. Mayansky A.N., Mayansky D.N. Ocherki o neytrofile $i$ makrofage [Essays on neutrophil and macrophage]. Novosibirsk: Nauka; 1989; 344 p.

17. Santos A.S., Finlay B.B. Bringing down the host: enteropathogenic and enterohaemorrhagic Escherichia coli effector-mediated subversion of host innate immune pathways. Cell Microbiol 2015; 17(3): 318-332, https://doi.org/10.1111/ cmi.12412. 